\title{
Effect of intra-rectal administration of boar seminal immunosuppressive fraction on mouse lymphocytes
}

\author{
L. Veselský ${ }^{1}$, J. Dostál ${ }^{2}$ and J. Drahorád ${ }^{1}$ \\ ${ }^{1}$ Institute of Molecular Genetics, Academy of Sciences of the Czech Republic, 16637 Prague, \\ Czech Republic; and ${ }^{2}$ Institute of Animal Physiology and Genetics, Academy of Sciences of the \\ Czech Republic, 27721 Liběchov, Czech Republic
}

\begin{abstract}
The repeated deposition of an immunosuppressive fraction isolated from boar vesicular gland secretion into the rectum of healthy male and female mice reduced responses of lymphocytes to mitogens in vitro. Rectal deposition of the immunosuppressive component also led to a decrease in the activity of plaque-forming cells. These findings indicate that repeated rectal deposition of semen may compromise some aspects of the immune system and may be an important cofactor in the development of viral or bacterial infections among homosexual men.
\end{abstract}

\section{Introduction}

Seminal plasma contains components that can suppress immune responses (Quayle and James, 1990) and syngeneic mouse spermatozoa injected i.v. are immunosuppressive as determined by mixed lymphocyte culture (Hurtenbach and Shearer, 1982). Spermatozoa are autoantigenic for males and isoantigenic for females. However, adults do not exhibit sensitization to spermatozoa.

The emergence of the acquired immune deficiency syndrome (AIDS) prompted us to investigate the immunosuppressive components in reproductive tract secretions. In homosexual men, the highest risk group for AIDS, immunological abnormalities are often observed without clinical signs of the disease (Krohn et al, 1985; McCune, 1991). These findings suggest that the infectivity or activity of AIDS-associated virus might depend on the immunity of the host. Seminal plasma inhibits the activity of most cells of the immune system and interferes with the generation and activity of some soluble components involved in the natural defence against infections (Emoto et al., 1990; Quayle et al., 1989). Semen deposition in the gut may play a role in the development of viral infections among homosexual men (Shearer and Rabson, 1984; Olsen and Shields, 1984).

Suppressive activity of seminal plasma in vitro can be assigned to spermine (Shohat et al., 1990) and the suppression of $\mathrm{T}$ lymphocytes in vivo requires the presence of spermine oxidase or related enzymes (Quan et al, 1990). Physicochemical characterization of human seminal plasma components provides evidence that transglutaminase and prostaglandins are the principal molecules contributing to seminal plasma immunosuppression of natural killer cells (Tarter et al., 1986; Ablin et al., 1990). Quayle et al. (1989) demonstrated that prostaglandins of the $\mathrm{E}$ series are almost entirely responsible for the immunosuppression of the natural killer cell system. However, the immunosuppressive component in boar seminal plasma has

Received 30 July 1993. no effect on the activity of natural killer cells (Bouvet et al., 1987; Veselský et al., 1992).

Human seminal plasma is lymphocytotoxic at high concentrations (Allen and Roberts, 1986) and the toxic effect of seminal plasma is enhanced by the presence of fetal calf serum. This serum contains a polyamide oxidase that oxidases spermine and spermidine to produce aldehydes that are highly cytotoxic. However, Szymaniec et al. (1987) showed that human seminal plasma suppresses lymphocyte responses in vitro in serum-free medium. We isolated and characterized a protein from boar vesicle gland secretion that inhibits the proliferation of murine lymphocytes in vitro and in vivo (Veselský et al., 1991). Immunosuppressive activity of the immunosuppressive component in vivo excluded the possibility of artefacts due to interactions with culture media.

In the present report male and female $\mathrm{BALB} / \mathrm{c}$ mice were used to investigate the effect on cellular immunity of an immunosuppressive fraction isolated from boar vesicular gland secretion and administered to experimental animals by rectal infusion.

\section{Materials and Methods}

\section{Isolation of immunosuppressive fraction}

The immunosuppressive fraction was isolated from boar vesicular gland secretion using the procedure described by Veselský et al. (1991). Vesicular gland secretion was precipitated in $8 \%$ ethanol at $\mathrm{pH} 7.2$ and $-2.5^{\circ} \mathrm{C}$. Samples, $100 \mathrm{mg}$, of the precipitate were dialysed and dissolved in PBS at $\mathrm{pH} 7.2$, and then applied to a Sephacryl S-200 column $(2.4 \mathrm{~cm} \times 63 \mathrm{~cm})$ equilibrated with PBS, pH 7.2, at a flow rate of $4.2 \mathrm{ml}$ for $15 \mathrm{~min}$. The fractions with inhibitory activity on leucocytes were pooled and run through a Sephadex G-75 column $(1.4 \mathrm{~cm} \times 94 \mathrm{~cm})$, equilibrated with $\mathrm{PBS}, \mathrm{pH} 7.2$, at a flow rate of $1.5 \mathrm{ml}$ for $20 \mathrm{~min}$. 


\section{Animals and treatments}

The effect of rectally infused immunosuppressive fraction on mouse lymphocytes was evaluated in two experiments. In the first experiment, five male and five female BALB/c inbred mice were anaesthetized with ether, and $0.5,1$ or $2 \mathrm{mg}$ of immunosuppressive fraction in $0.1 \mathrm{ml}$ of saline was deposited in the rectum, by means of a catheter to a depth of $4 \mathrm{~cm}$, on days 0 , 3 and 6 . This treatment did not damage any part of rectal mucosa as faeces passed afterwards were examined and found to be heme negative. Control mice were treated with saline or BSA in the same manner. In all mice, spleen lymphocytes were separated 3 days after the last deposition and assayed in the mitogen-induced lymphocyte proliferation test.

In the second experiment the effect of immunosuppressive fraction in vivo was evaluated by the plaque-forming assay. Five male and five female mice were rectally infused with 0.5 , 1 or $2 \mathrm{mg}$ of immunosuppressive fraction in $0.1 \mathrm{ml}$ of saline and the same time injected i.p. with $1 \times 10^{8}$ sheep erythrocytes. Sheep erythrocytes were obtained from blood collected into heparinized tubes by venepuncture of donor animals. After 24 and $48 \mathrm{~h}$, the mice received another rectal infusion of $0.5, \mathrm{I}$ or $2 \mathrm{mg}$ of immunosuppressive fraction. Control mice were treated with saline or BSA (2 mg per mouse). Spleen lymphocytes were separated on day 5 after the first rectal infusion and tested in the plaque-forming assay.

\section{Mitogen-induced lymphocyte proliferation test}

Seventy-two hours after the final rectal infusion of immunosuppressive fraction, the mice were killed by cervical dislocation. The spleens of the treated mice were aseptically removed, minced with fine scissors, suspended in RPMI 1640 medium (Institute for Sera and Vaccines, Prague), and the cell suspension was passed through a fine screen. Splenocytes were washed twice by centrifugation $(10 \mathrm{~min}$ at $1000 \mathrm{~g}$ ). The final splenocyte concentration was adjusted to $2 \times 10^{6} \mathrm{cells} \mathrm{ml}^{-1}$ in RPMI 1640 medium supplemented with $10 \%$ BSA, $2 \mathrm{mmol}$ L-glutamine $1^{-1}, 100 \mathrm{iu}$ penicillin $\mathrm{ml}^{-1}$ and $0.1 \mathrm{mg}$ streptomycin $\mathrm{ml}^{-1}$. The splenocyte cultures, performed in triplicate in 96-well flat-bottomed culture plates, were stimulated with $0.005 \mathrm{mg}$ pokeweed mitogen (Sigma, St Louis, MO) or $0.05 \mathrm{mg}$ phytohaemagglutinin (Wellcome Research Laboratories, Dartford) $\mathrm{ml}^{-1}$ RPMI 1640 medium. The lymphocytes were cultured for $72 \mathrm{~h}$ at $38^{\circ} \mathrm{C}$. After $48 \mathrm{~h}$ of culture, $37 \mathrm{kBq}$ methyl- $\left[{ }^{3} \mathrm{H}\right]$ thymidine (specific activity $840 \mathrm{GBq} \mathrm{mmol}^{-1}$, Institute for Research, Production and Application of Radioisotopes, Prague) per well was added. The cells were collected onto glass-fibre discs using a semi-automatic harvester and the radioactivity was measured using a standard liquid scintillation technique. In all cultures, the viability of the lymphocytes was greater than $95 \%$ as determined by trypan blue exclusion.

\section{Plaque-forming assay}

Experimental animals were killed by cervical dislocation and spleen lymphocytes were collected on day 5 after immunization with sheep erythrocytes. Splenocytes, $0.1 \mathrm{ml}\left(10^{6}\right.$ cells $\mathrm{ml}^{-1}$ RPMI 1640 medium), were mixed with $0.05 \mathrm{ml} 10 \%$ sheep erythrocytes and $0.05 \mathrm{ml}$ guinea-pig complement (Insti- tute for Sera and Vaccines, Prague) preabsorbed with sheep erythrocytes. The mixture was pipetted into a chamber made of two microscope slides. After incubation for $2 \mathrm{~h}$ at $37^{\circ} \mathrm{C}$, the plaque-forming cells were counted.

\section{Statistical analysis}

Statistical significance of the results was calculated using Student's $t$ test.

\section{Results}

In the five male and five female mice treated with 1 or $2 \mathrm{mg}$ of immunosuppressive fraction, the blastogenic response of lymphocytes stimulated by pokeweed mitogen and phytohaemagglutinin was significantly reduced $(P<0.01)$ (Table 1$)$. The experiments were repeated three times with the same number of mice per group. The inhibition of the blastogenic response by the immunosuppressive fraction was comparable among experimental groups. No sex-related difference in sensitivity to the immunosuppressor was observed.

A similar inhibitory activity was obtained in the experiments in vivo. The rectal infusion of $2 \mathrm{mg}$ immunosuppressive fraction caused $68 \%(P<0.01)$ suppression of plaque-forming cells. With $1 \mathrm{mg}$ immunosuppressive fraction the inhibition was $52 \%$ $(P<0.01)$. With the infusion of $0.5 \mathrm{mg}$, the suppression was only $10 \%$ (Table 2 ). The experiments were repeated three times with five male and five female mice per group. The suppression of plaque-forming cells by immunosuppressive fraction was comparable among experimental groups and no sex-related difference was observed.

\section{Discussion}

Seminal plasma suppresses a variety of immunological functions in vitro and in vivo (Quayle et al., 1989; Veselský et al., 1991) and recent studies have indicated that rectal insemination of homologous semen into rabbits had several consequences. Spermatozoa in the rectum evoked the formation of antibodies (Richards et al., 1984), in spite of the fact that seminal plasma is immunosuppressive (Kelly, 1991). It was concluded in studies of natural killer cell function that prostaglandins in semen are responsible for this inhibition (Quayle et al., 1989). It was also demonstrated that cellular immune functions, including natural killer cell activity and mitogen stimulation, were not reduced after a single rectal insemination of human seminal plasma into Rhesus monkeys. Prostaglandin $\mathrm{E}_{2}$ metabolite values in blood plasma were high in the inseminated monkeys but not in the control monkeys (Alexander et al., 1986). Intra-rectal infusion of $\mathrm{PGE}_{2}$ or $\mathrm{PGD}_{2}$ into male rats reduced responses of $\mathrm{T}$ cells to phytohaemagglutinin in vitro but the T-cell response of female rats was not significantly reduced (Kuno et al., 1986). Boar seminal plasma contains extremely low concentrations of prostaglandins $\left(0.01 \mathrm{mg} \mathrm{ml}{ }^{-1}\right)$ compared with prostaglandin concentrations in human seminal plasma $\left(0.578 \mathrm{mg} \mathrm{ml}^{-1}\right)$ (Mann and Lutwak-Mann, 1981). Moreover, it has been found that immunosuppressive molecules in boar seminal plasma have no effect on cells involved in transplantation events, including 
Table 1. Effect of intra-rectal administration of boar seminal immunosuppressive fraction to mice evaluated by mitogen-induced lymphocyte proliferation test

\begin{tabular}{|c|c|c|c|c|}
\hline Infusion & PHA $\left(50 \mu \mathrm{g} \mathrm{ml}^{-1}\right)$ c.p.m. $\pm \mathrm{SD}$ & Percentage inhibition & PWM $\left(5 \mu \mathrm{g} \mathrm{ml}^{-1}\right)$ c.p.m. $\pm \mathrm{SD}$ & Percentage inhibition \\
\hline Saline & $70062 \pm 3474$ & & $39658 \pm 6174$ & \\
\hline Albumin & $72136 \pm 4070$ & & $37630 \pm 4051$ & 4 \\
\hline ISF ( $2 \mathrm{mg})$ & $17071 \pm 2859$ & 74 & $7255 \pm 1399$ & $82^{*}$ \\
\hline Saline & $82200 \pm 6265$ & & $21458 \pm 2305$ & \\
\hline Albumin & $79672 \pm 4563$ & 4 & $22931 \pm 2751$ & \\
\hline ISF (1 mg) & $31352 \pm 2759$ & $62^{*}$ & $9428 \pm 1739$ & $56^{*}$ \\
\hline Saline & $29147 \pm 2843$ & & $44426 \pm 3858$ & \\
\hline Albumin & $31615 \pm 3518$ & & $46358 \pm 2318$ & \\
\hline ISF $(0.5 \mathrm{mg})$ & $26025 \pm 2760$ & 11 & $35751 \pm 3975$ & 19 \\
\hline
\end{tabular}

$* P<0.01$

ISF: immunosuppressive fraction; PHA: phytohaemagglutinin; PWM: pokeweed mitogen.

Table 2. Effect of intra-rectal administration of boar seminal immunosuppressor to mice evaluated by inhibition of plaqueforming cells

\begin{tabular}{lccc}
\hline Infusion & $\begin{array}{c}\text { Number } \\
\text { of mice }\end{array}$ & $\begin{array}{c}\text { Plaque-forming cells } \\
\text { (average of group) } \\
( \pm \mathrm{SD})\end{array}$ & $\begin{array}{c}\text { Percentage } \\
\text { inhibition }\end{array}$ \\
\hline Saline & 5 & $615 \pm 48$ & \\
Albumin & 5 & $621 \pm 65$ & \\
ISF (2 mg) & 5 & $197 \pm 29$ & $68^{*}$ \\
ISF (1 mg) & 5 & $295 \pm 31$ & $52^{*}$ \\
ISF (0.5 mg) & 5 & $553 \pm 57$ & 10 \\
\end{tabular}

Values represent the means $\pm \mathrm{SD}$ for five mice per group. The number of plaque-forming cells was calculated per $10^{6}$ spleen cells. No sex-related difference in sensitivity to immunosuppressor was observed.

${ }^{*} P<0.01$.

ISF: immunosuppressive fraction.

natural killer cell activity (Veselský et al., 1992). Our results show that components other than prostaglandins, administered via the rectum cause a decrease in the lymphocyte response in vivo. Rectal intercourse is a common sexual activity among homosexual men and, as indicated, the seminal molecules can be absorbed by the recipients via the rectum. $A$ sex-related difference in the sensitivity to prostaglandins has been observed and a possible explanation is that females should be naturally more resistant to prostaglandins (Kuno et al., 1986). Nevertheless, our results indicate that seminal plasma contains other components with immune dysregulation consequences in males and females.

Inhibition of the function of immunocompetent cells would contribute to the development of malignancies and pathological changes caused by infections. Two of the most disturbing diseases associated with sexually transmitted viruses are cervical cancer and acquired immune deficiency syndrome. Sexually transmitted viruses have been proposed as possible carcinogens and Mitchell et al. (1986) suggested that the human papilloma virus is a viral agent. The primary agent causing AIDS, the human immunodeficiency virus (HIV), is found in blood and semen. The most effective way of transmitting HIV is by cell contact. However, the infection was evidenced after the inoculation of HIV into the vaginal mucosa (Fultz et al., 1986). Mucosal transmission of HIV by the vaginal mucosa in heterosexual, or rectal mucosa in homosexual subjects could be responsible for $70-80 \%$ of AIDS (Lehner et al., 1991).

Spermatozoa express a number of sperm-specific antigens that can elicit the immune response in sexual partners (Alexander and Anderson, 1987). Although lymphocyte function may be impaired by immunosuppressive factors in seminal plasma, macrophages in semen retain the phagocytic, adherent and motile functions (Anderson and Hill, 1989). Seminal immunosuppressive factors may locally suppress immune defence mechanisms in the female reproductive tract and, thereby, protect spermatozoa and other seminal cells in the female reproductive tract. Potent anticomplement immunosuppressive factors could suppress even humoral defence mechanisms in reproductive tissues (Tarter and Alexander, 1984). In addition, excessive exposure to seminal plasma at sites other than the urogenital tract may have a systemic effect. Seminal components may gain access to the circulation if they are deposited in the gastrointestinal tract, especially if it has been traumatized (James and Hargreave, 1984).

We postulate that absorption of seminal plasma may be a factor in the aetiology of AIDS and other viral infections in males and females. High concentration of immunosuppressive molecules might reduce host defence mechanisms, especially after repeated exposure.

The authors thank M. Hǒsková and L. Koberová for their excellent technical assistance. This work was supported by grant No. 310/93/ 0307 from the Grant Agency of the Czech Republic.

\section{References}

Ablin RJ, Bartkus JM and Polgar J (1990) Effect of human seminal plasma on the lytic activity of natural killer cells and presumptive identification of participant macromolecules American Joumal of Reproductive Immunology 24 $15-21$ 
Alexander NJ and Anderson DJ (1987) Immunology of semen Fertility and Sterility 47 192-205

Alexander NJ, Tarter TH, Ducsay CA, Fulgham DL and Huso N (1986) Rectal absorption of semen Journal of Reproductive Immunology 10 Abstract 82

Allen RD and Roberts TK (1986) The relationship between the immunosuppressive and cytotoxic effect of human seminal plasma American Journal of Reproductive Immunology and Microbiology 11 59-64

Anderson DJ and Hill JA (1989) Immunological aspects of the reproductive organs and implications of intercourse Current Opinion in Immunology 1 $1119-1124$

Bouvet JP, Couderc J and Pillot J (1987) In vivo and in vitro immunosuppression in mice by a $100-110 K_{d}$ fraction from boar seminal plasma American Journal of Reproductive Immunology and Microbiology 14 135-140

Emoto M, Kita E, Nishikava F, Katsui N, Namuro A, Oku D and Kashiba S (1990) Biological function of mouse seminal vesicle fluid. II. Role of water-soluble fraction of seminal vesicle fluid as a monospecific immunomodulator Archives of Andrology 25 75-84

Fultz PN, McClure HM, Daugharty H, Brodie A, McGrath CR, Swenson B and Francis DP (1986) Vaginal transmission of human immunodeficiency virus (HIV) to a chimpanzee. Joumal of Infectious Diseases 154 896-900

Hurtenbach U and Shearer GM (1982) Germ cell-induced immune suppression in mice: effect of inoculation of syngeneic spermatozoa on cell-mediated immune responses Journal of Experimental Medicine 155 1719-1729

James K and Hargreave TB (1984) Immunosuppression by seminal plasma and its possible clinical significance Immunology Today 5 357-363

Kelly RW (1991) Seminal plasma immunosuppressive activity - the Achilles' heel of reproduction International Journal of Andrology 14 243-247

Krohn K, Ranki A, Antonen J, Valle SL, Suni J, Vahari A, Saxinger C and Gallo RC (1985) Immune functions in homosexual men with antibodies to HTLV-III in Finland Clinical and Experimental Immunology 60 17-24

Kuno S, Ueno R and Hayashi O (1986) Prostaglandin $E_{2}$ administered via anus causes immunosuppression in male but not female rats: a possible pathogenesis of acquired immune deficiency syndrome in homosexual males Proceedings of the National Academy of Sciences, USA 83 2682-2683

Lehner T, Hussain L, Wilson J and Chapman M (1991) Mucosal transmission of HIV Nature 353709

McCune JM (1991) HIV-1: the infective process in vitro Cell 64 351-363

Mann T and Lutwak-Mann C (1981) Prostaglandins and other organic acids. In Male Reproductive Function and Semen pp 312-317 Eds T Mann and C Lutwak-Mann. Springer Verlag, New York
Mitchell H, Drake M and Medley G (1986) Prospective evaluation of risk of cervical cancer after cytological evidence of human papilloma virus infection Lancet i 573-575

Olsen GP and Shields JW (1984) Seminal lymphocytes, plasma and AIDS Nature 309 116-117

Quan CP, Roux C, Pillot J and Bouvet JP (1990) Delimination between T and B suppressive molecules from human seminal plasma. II. Spermine is the major suppressor of T-lymphocytes in vitro American Journal of Reproductive Immunology 22 64-72

Quayle AJ and James K (1990) Immunosuppression by seminal plasma and its possible biological significance Archivum Immunologiae et Therapiae Experimentalis 38 87-100

Quayle AJ, Kelly RW, Hargreave TB and James K (1989) Immunosuppression by seminal prostaglandins Clinical and Experimental Immunology 75 387-391

Richards JM, Bedford JM and Witkins SS (1984) Rectal insemination modifies immune responses in rabbits Science 224 390-392

Shearer GM and Rabson AS (1984) Semen and AIDS Nature 308230

Shohat B, Maayan R, Singer R, Sagiv M, Kaufman H and Zukerman Z (1990) Immunosuppressive activity and polyamine levels of seminal plasma in azo-ospermic, oligospermic and normospermic men Archives of Andrology 24 $41-50$

Szymaniec S, Quayle AJ, Hargreave TB and James K (1987) Human seminal plasma suppresses lymphocyte responses in vitro in serum-free medium Joumal of Reproductive Immunology 12 191-200

Tarter TH and Alexander NJ (1984) Complement-inhibiting activity of seminal plasma American Journal of Reproductive Immunology 6 28-32

Tarter TH, Cunningham-Rundles S and Koida S (1986) Suppression of natural killer cell activity by human seminal plasma in vitro: identification of 19-OH-PGE as the suppression factor Joumal of Immunology 136 2862-2868

Veselský L, Čechová D, Hošková M, Štědra J, Holáñ V and Staněk R (1991) In vivo and in vitro immunosuppression by boar seminal vesicle fluid fraction International Joumal of Fertility 36 183-188

Veselský L, Holáň V, Soucěk J, Staněk R and Hošková M (1992) Effect of boar seminal plasma immunosuppressive factor on NK cell activity and skin graft survival International Journal of Fertility 37 358-361 